\title{
Purification and Cytotoxicity of L-asparaginase from Streptomyces griseoluteus GDJ1
}

\author{
Dhanam Jayam G', Kannan $S^{2}$, Anand S.B ${ }^{3}$ \\ ${ }^{1,2}$ Department of Environmental Studies, School of Energy, Environment and Natural Resources, Madurai Kamaraj University, Madurai, \\ ${ }^{3}$ Department of Genetic Engineering, School of Biotechnology, Madurai Kamaraj University, Madurai
}

\begin{abstract}
L-asparaginase (L-asparagine amidohydrolase E.C.3.5.1.1) is an effective antineoplastic enzyme, used in acute lymphoblastic leukemia (ALL) chemotherapy. L-asparaginase activity of marine actinomycetes in soil samples of Agnitheertham (Rameswaram) and Periyar lake, Kumily were investigated. Totally fifty one actinomycetes were isolated from both the soil samples in different selective media. Out of fifty one isolates, four were found to produce L-asparaginase. Among them, the strain AT-R-S1 produced high amount of L-asparaginase. Hence it was selected for the further identification and based on molecular identification the strain AT-R-S1 was identified as Streptomyces griseoluteus GDJ1. Purification of the enzyme from the strain S.griseoluteus GDJ1 (AT$R-S 1)$ was carried out. The final purification of the enzyme in CM-Sephadex C-50 column chromatography yielded $1.27 \mathrm{U} / \mathrm{ml}$ of enzyme in $0.09 \mathrm{mg}$ of protein with a specific activity of $14.11 \mathrm{U} / \mathrm{mg}$ with approximately 119 folds purity. Cytotoxicity of different concentration of purified L-asparaginase was determined on VERO cells. The anti proliferative activity of L-asparaginase in MCF-7 and HeLa cells was determined and the $\mathrm{EC}_{50}$ value was found to be 31.37 and $38.99 \mu \mathrm{g}$ respectively. The above results were encouraging and worth pursuing for further development of Streptomyces griseoluteus GDJI (AT-R-S1) as an alternative resource for therapeutic L-asparaginase.
\end{abstract}

Keywords: Actinomycetes, L-asparaginase, Purification, Anticancer

\section{Introduction}

All enzymes are proteins composed of amino acids, (in some cases RNA molecules) that catalyse reaction involved in development and maintenance of cell and help in defense against diseases with great specificity[1]. Enzymes act on their targets with higher affinity and specificity and convert multiple target molecules to desired products. Enzymes are being used to treat many diseases like cancer, dermal ulcers, inflammation, cardiac problems, cystic fibrosis and digestive disorders etc [2]. A major potential application of therapeutic enzymes is in the treatment of cancer. Cancer is the most precarious disease in which abnormal cells proliferate rapidly without control and able to invade other tissues by lymph or blood systems [1] and can cause organ failure and death if untreated. Globally, in 2012 nearly 14.1 million new cancer cases and 8.2 million deaths were occurred due to cancer [3] and by 2030 the number is expected to increase to 21 million. In India, 462408 male cancer patients and 517378 female cancer patients were recorded, with a total number of 979786 patients in 2010 with total economic loss of 270.06 million US \$ For treating cancer numerous drugs are available includes, asparaginase, daunorubicin, cyclophosphamide, mercaptopurine, methotrexate etc [4] and new products have been synthesized and tested for their anti cancer activity. However, radiotherapy and chemotherapy has been the mainstay to treat cancer which has deleterious effects to the patients by making them prone to other diseases and weakening their immune system. Hence the exploration of novel therapeutic drug for the treatment of life threatening cancer is in immense need of the hour. L-asparaginase, one of the anti cancer drug used to treat several leukemias, lymphomas, lymphoproliferative disorders, lymphosarcoma, Hodgkin's disease, acute myelogenous leukemia, acute myelomonocytic leukemia, chronic lymphocytic leukemia, reticulosarcoma, melanosarcoma and acute lymphoblastic leukemia [5]. Lasparagine is an essential amino acid required for the growth of normal cells, L- asparagine can be obtained by either diet or by the synthesis via asparagine synthetase located on the chromosome number $7(7 \mathrm{q} 21.3)$ in humans [6]. The starvation of L-asparagine due to lack or less activity of asparagine synthetase tumor cells cannot synthesis their own L-asparagine and depends on the external sources. The breakdown of circulating pool of L-asparagine by Lasparaginase resulted in reduced RNA and protein synthesis, causes cell cycle arrest in the G1-phase and ultimately apoptosis in susceptible leukemic cells [7]. Hence, the normal cells are not affected during the treatment with Lasparaginase since their ability to produce this amino acid [8]. L-asparaginase is a relatively wide spread enzyme found in many micro organisms. Out of the different sources explored, L-asparaginase from E.coli gained momen tum and after several studies and subsequent clinical trials, it was approved as drug for leukemia by FDA in 1978. Glutamine a co-substrate of L-asparaginases, depreciated by the action of L-asparaginase which has intrinsic glutaminase activity that cause serious side effects such as leucopenia, immunosuppression, acute pancreatitis, thromboembolysis, hyperglycemia and neurological seizures [9]. Protein synthesis was found to be reduced when the glutamine is reduced to a critical level. Further, the multiple administration of such enzyme protein for a long duration produces anti asparaginase antibodies in the tissues, resulting in anaphylactic shock and may also cause neutralization of drug effect by the host immune system. Therefore, glutaminase free and new serologically different Lasparaginase with a similar or higher therapeutic effect than the previously reported ones is urgently required. Considering the above facts, an attempt an attempt was made 


\section{International Journal of Science and Research (IJSR) \\ ISSN (Online): 2319-7064 \\ Index Copernicus Value (2015): 78.96 | Impact Factor (2015): 6.391}

to isolate, screen, purify and to determine the anticancer activity of L-asparaginase from the soil sample isolated from Agnitheertham of Rameswaram and Periyar lake.

\section{Material and Methods}

\subsection{Isolation of Actinomycetes}

Soil samples were air dried aseptically. After a week sample was incubated at $55^{\circ} \mathrm{C}-5 \mathrm{~min}$ inorder to facilitate the isolation of actinomycetes. Then tenfold serial dilution was prepared with one gram of soil sample using distilled water. Samples wereinoculated on Starch Caesin agar (SCA), Actinomycetes Isolation Agar (AIA) and Glycerol Asparagine agar (ISP-5 Medium) in triplicate plates. Streptomycin $(20 \mu \mathrm{g} / \mathrm{ml})$ and cycloheximide $(50 \mu \mathrm{g} / \mathrm{ml})$ were added to the medium inorder to retard the growth of bacteria and fungi respectively. All the plates were incubated at $28 \pm$ $2^{\circ} \mathrm{C}$ for 7 days. Colonies with suspected Actinomycetes morphology (i.e., isolates with grey and white colonies) were purified using yeast-extract malt extract agar medium. The pure cultures of the actinomycetes were streaked on SCA, AIA and ISP-5 Medium plates [12], [13].

\subsection{Screening of L-asparaginase Producers}

The isolated colonies were screened for L-asparaginase production by rapid plate assay technique described by Gulati et al., [10]. Modified agar plates of M-9 and CzapekDox agar supplemented with $0.1 \%$ of L-asparagine $(\mathrm{w} / \mathrm{v})$, $0.009 \%$ of phenol red (v/v) were prepared and streaked with the isolated colonies and incubated at $28 \pm 2{ }^{\circ} \mathrm{C}$ for five days. After incubation the plates were observed for the pink colour formation around the colonies and considered as positive L asparaginase producers.

\subsection{Enzyme Quantification}

To $100 \mu \mathrm{L}$ of the enzyme extract, $200 \mu \mathrm{L}$ of $0.05 \mathrm{M}$ Tris$\mathrm{HCl}$ buffer $(\mathrm{pH} 8.2)$ and $1.7 \mathrm{~mL}$ of $0.01 \mathrm{M} \mathrm{L}$-asparagine as substrate were added and incubated at $37^{\circ} \mathrm{C}$ for $10 \mathrm{~min}$. After incubation, the reaction was stopped by adding $500 \mu \mathrm{L}$ of $1.5 \mathrm{M}$ TCA. The resulting mixture was centrifuged at $1000 \mathrm{rpm}$ at $4^{\circ} \mathrm{C}$. The supernatant was transferred to new tube and $0.5 \mathrm{~mL}$ of the supernatant was diluted with $6.5 \mathrm{~mL}$ of distilled water and $200 \mu \mathrm{L}$ of Nesslers reagents and left for $10 \mathrm{~min}$ for the development of yellow color. Then the OD was measured at $450 \mathrm{~nm}$ using UV-Visible Spectrophotometer (Shimadzu, ). The absorbance was then compared to the standard curve of ammonium sulfate and the $\mu \mathrm{M}$ of ammonia released was calculated. From the ammonia released the L-asparaginase activity (Unit/mL) was calculated using the following formula

Units $/ \mathrm{mL}=\frac{\left(\mu \text { mole of } \mathrm{NH}_{3} \text { liberated }\right) \times(\text { Initial volume of enzyme mixture }(\mathrm{mL})}{\begin{array}{l}\text { Volume of enzyme mixture used in final reaction }(\mathrm{mL}) \times \\ \text { (Incubation time }(\mathrm{min})) \times(\text { Volume of enzyme used }(\mathrm{mL}))\end{array}}$
One International unit of L-asparaginase was defined as the amount of enzyme which liberates one $\mu$ mole of ammonia in one $\min$ at $37^{\circ} \mathrm{C}[11]$

\subsection{Identification of Actinomycetes}

\subsubsection{Morphological and Biochemical Characterization} In order to determine the organism at the genus level, morphological and biochemical tests were carried out based on the International Streptomyces Project (ISP). Cell morphology and motility were determined by microscopic examination (Labomed Asia model No. LB-210). Gram staining was performed according to the manufactures (Himedia Lab, India) instructions. Catalase activity was performed by adding $\mathrm{H}_{2} \mathrm{O}_{2}$ to a fresh loop full of culture placed on clean glass slides. The hydrolysis of starch and casein was determined on the plates of SCA containing $0.4 \%$ starch and $5 \%$ of skimmed milk powder, respectively. The acid production during utilization of carbohydrate was determined in tryptone broth supplemented with 1 percent of $(\mathrm{w} / \mathrm{v})$ anyone of the following substrates: Arabinose, Glucose, Raffinose, Sucrose, Xylose, Fructose, Mannitol, Inositol and Lactose. The bromocresol purple $(0.001 \%)$ was added to each tube as an indicator of acid production. Growth at different temperatures $\left(4\right.$ to $\left.65^{\circ} \mathrm{C}\right)$, different $\mathrm{pH}$ (5.0-10.0) were tested in SCA broth and salt tolerance was performed at $30^{\circ} \mathrm{C}$ in SCA broth supplemented with 2 to 10 percent $\mathrm{NaCl}$. Reduction of nitrate, and production of indole, gelatinase, urease, acetoin (Voges-Proskauer-VP), $\mathrm{H}_{2} \mathrm{~S}$ and utilization of citrate were also performed.

\subsubsection{Genotypic characterization of isolates}

\subsubsection{Isolation of Genomic DNA}

Each isolate was inoculated in $100 \mathrm{~mL}$ Erlenmeyer flask containing $20 \mathrm{~mL}$ of SCA broth and incubated in an orbital shaker incubator (Remi CIS-24 Plus, India) at $150 \mathrm{rpm}$ at $30^{\circ} \mathrm{C}$. After 3 days, two milliliters of cultures were transferred into micro centrifuge tube and centrifuged at $10,000 \mathrm{~g}$ for $2 \mathrm{~min}$. The pellet was resuspended in $2 \mathrm{~mL}$ of lysis buffer, vortexed for $1 \mathrm{~min}$ and incubated at $37^{\circ} \mathrm{C}$ for 30 min. SDS (final concentration $1 \% \mathrm{w} / \mathrm{v}$ ) and proteinase $\mathrm{K}$ (final concentration $100 \mathrm{mg} \mathrm{mL}^{-1}$ ) was added, vortexed for $10 \mathrm{~s}$ and incubated at $55^{\circ} \mathrm{C}$ for $2 \mathrm{~h}$. An equal volume of phenol-chloroform-isoamyl alcohol (24:23:1) was added and mixed it by inverting the tubes several times and centrifuged at $10,000 \mathrm{~g}$ for $15 \mathrm{~min}$. The aqueous layer (upper) was transferred to a new tube and the extraction was repeated once. The obtained aqueous phase was again transferred to a new tube and the DNA was precipitated by adding $1 / 10^{\text {th }}$ volume of $3 \mathrm{M}$ sodium acetate and 0.6 to 1 volume of ice cold 2-propanol and mixed gently. Then the tubes were incubated at $-20^{\circ} \mathrm{C}$ from $1 \mathrm{~h}$ to overnight. The mixture was centrifuged at $10,000 \mathrm{~g}$ for $15 \mathrm{~min}$, the supernatant was discarded and DNA was washed with $500 \mu \mathrm{L}$ of 70 percent ethanol. Again it was centrifuged at $10,000 \mathrm{~g}$ for $5 \mathrm{~min}$ and finally the ethanol was carefully discarded and air dried until ethanol removed. The precipitated DNA was resuspended in $200-300 \mu \mathrm{L}$ of double-distilled sterile water. It was allowed to dissolve at $37^{\circ} \mathrm{C}$ at least $3 \mathrm{~h} \mathrm{[15].}$ 


\section{International Journal of Science and Research (IJSR) \\ ISSN (Online): 2319-7064}

Index Copernicus Value (2015): 78.96 | Impact Factor (2015): 6.391

\subsubsection{Polymerase Chain Reaction (PCR)}

The Polymerase Chain Reaction (PCR) technique was employed to amplify the tar get gene or region. In brief, a region lying between a forward and reverse primer was amplified in an exponential fashion in the presence of appropriate reagent and cycling condition. The successful amplification of all reactions was assessed on agarose gels prepared with 1X TBE (Tris Boric acid EDTA).

\subsubsection{Agarose Gel Electrphoresis}

Gel tray and comb was prepared by wiping with 70 percent ethanol and air dried for $5 \mathrm{~min}$. The required concentration of agarose was added in $1 \mathrm{X} \mathrm{TBE}$ and the mixture was left for 10-15 $\mathrm{min}$ (to enhance the solubilization). Later, it was heated in a microwave oven for 2-3 min until the solution was clear. This molten agarose solution was left to cool around $60^{\circ} \mathrm{C}$ without disturbance. Then, ethidium bromide (final concentration $0.5 \mu \mathrm{g} \mu \mathrm{L}^{-1}$ ) was added, mixed thoroughly by swirling the container gently and the solution was poured into a prepared gel tray. The agarose gel was allowed to set at room temperature for 20-30 $\mathrm{min}$. The solidified agarose gel (along the tray/comb) was stored in a refrigerator for another 20-30 min before use. Electrophoresis of the gel was performed in a gel tank with 1X TBE at appropriate volt and run time. The presence of specific band was confirmed under ultraviolet (UV) light visualization and documented (UVP- Multidoc-It, USA)

\subsubsection{PCR amplification of 16S rDNA}

The DNA extracted by phenol chloroform method was used as PCR template for $16 \mathrm{~S}$ rDNA amplification. The polymerase chain reaction was carried out with universal forward $(27 \mathrm{~F})$ and reverse (1492R) primers. The PCR reaction mixture $(50 \mu \mathrm{L})$ consisted of $50 \mathrm{ng}$ of genomic DNA in $2 \mu \mathrm{L}, 1 \mathrm{X}$ PCR buffer with $2.0 \mathrm{mM} \mathrm{MgCl}_{2}, 200 \mu \mathrm{M}$ $\mathrm{dNTP}$, specific primers at required concentration and 0.5 units of T.aq DNA polymerase (Genetbio Inc, South Korea). The primer concentrations and cycling conditions were given in Table 5 and the PCR component composition was given in appendix 1. Amplified products were separated on 1.5 percent agarose gel containing $0.5 \mu \mathrm{g} / \mu \mathrm{L}$ ethidium bromide for $20 \mathrm{~min}$ at $100 \mathrm{~V}$ and documented under UV illumination

\subsubsection{DNA sequencing}

Nucleotide sequences were determined by using ABI 3730xl 96 Capillary Genetic Analyzer using big dye terminator v3.1 kit (Applied Biosystems) at Xcelris Labs Ltd., Ahmedabad, India. The sequenced PCR products were analyzed online using BLAST software (http://www.ncbi.nlm.nih.gov/blast) and the identity of the sequences were determined (Altschul et al., 1990).

\subsubsection{Multiple sequence alignment and phylogenetic} tree construction

All the nucleotide sequences were converted into FASTA format. Multiple sequence alignment for the assembled nucleotide sequences was done by using the Clustal X program (Thompson et al., 1997) in BIOEDIT software (Hall, 1999). Aligned sequences were imported into an MEGA 6: Molecular Evolutionary Genetics Analysis (MEGA) software version 6.0 (Tamura et al., 2011) software for further analysis. The ends of the alignment were trimmed to obtain equal lengths for all sequences and the aligned sequences were converted into MEGA format for carrying out phylogenetic analysis. The phylogenetic tree was constructed using the Neighbor-Joining method (Saitou and Nei, 1987) using nucleotide based TN84 evolutionary model for estimating genetic distances based on synonymous and non synonymous nucleotide substitutions. Statistical support for branching was estimated using 1000 bootstrap steps

\subsection{Purification of L-asparaginase}

The purification of L-asparaginase was carried out on the crude extract adapted by Distasio et al. [14].

\subsubsection{Ammonium sulphate precipitation}

Proteins can be concentrated from a culture by salting out method using ammonium sulphate precipitation at $40^{\circ} \mathrm{C}$. Finely powdered ammonium sulphate was added to the crude extract pinch by pinch on a magnetic stirrer. The Lasparaginase activity was associated with the fraction precipitated at $75 \%$ saturation. The pellet was collected by centrifugation at $10,000 \mathrm{rpm}$ for $10 \mathrm{~min}$ to which $5 \mathrm{~mL}$ of sodium phosphate buffer $(0.05 \mathrm{M}, \mathrm{pH} 7.8)$ was added. This resuspended pellet in phosphate buffer was further purified by dialysis.

\subsubsection{Dialysis}

Dialysis was carried out followed by ammonium sulphate precipitation to remove un-desirable molecules and ions of small size from high molecular weight particles like proteins, enzymes etc. The dialysis bag ( $15 \mathrm{kD}$ cutoff) is previously soaked in $0.05 \mathrm{M}$ phosphate buffer and the resuspended pellet in phosphate buffer was poured to the dialysis bag, sealed tightly and placed inside the $0.005 \mathrm{M}$ phosphate buffer for $12 \mathrm{~h}$ at $4^{\circ} \mathrm{C}$. After dialysis the samples were collected and treated as partially purified enzyme.

\subsubsection{Sephadex G-100 Gel Filtration}

The dialyzed ammonium sulphate fraction was applied to a Sephadex G-100 column that was pre-equilibrated with 0.01 $\mathrm{M}$ phosphate buffer ( $\mathrm{pH} 8.5)$. The protein elution was done with the same buffer at a flow rate of $5 \mathrm{~mL} / \mathrm{min}$. The fractions were collected using a fraction collector at $4^{\circ} \mathrm{C}$. The active fractions were pooled, dialyzed against the 0.01 $\mathrm{M}$ phosphate buffer $\mathrm{pH} 8.5$, and concentrated. Then the enzyme was subjected to CM-Sepahdex C-50 Ion Exchange Chromatography for further purification

\subsubsection{CM-Sephadex C50 Ion-Exchange Chromatography}

The concentrated enzyme solution was applied to the column of CM-Sephadex C50 that was pre-equilibrated with a 0.01 $\mathrm{M}$ phosphate buffer ( $\mathrm{pH} 8.5)$. The enzyme solution was then eluted with the $\mathrm{NaCl}$ gradient $(0.1-0.5 \mathrm{M})$ and $0.1 \mathrm{M}$ borate buffer, $\mathrm{pH}$ 7. The active fractions were collected, dialyzed, concentrated, and lyophilized and the enzyme was quantified.

\subsection{Assessment of cytotoxicity and anti-proliferative activity}

Cell cytotoxicity and anti-proliferative effect of Lasparaginase was performed using VERO used as control 


\section{International Journal of Science and Research (IJSR) \\ ISSN (Online): 2319-7064}

Index Copernicus Value (2015): 78.96 | Impact Factor (2015): 6.391

cell lines (Kidney Epithelial cells), MCF-7 (Human Breast Adenocarcinoma) and HeLa cell lines (Cervical cancer cell lines). The cells were plated separately in 96 well plates at a concentration of $1 \times 10^{5}$ cells/well. After $24 \mathrm{~h}$, cells were washed twice with $100 \mu \mathrm{l}$ of serum-free DMEM medium and starved for an hour at $37^{\circ} \mathrm{C}$. After starvation, cells were treated with different concentrations of L-asparaginase (5 $45 \mu \mathrm{g} / \mathrm{ml}$ ) for $72 \mathrm{~h}$. At the end of the treatment period the medium was aspirated and serum free medium containing MTT $(0.5 \mathrm{mg} / \mathrm{ml})$ was added and incubated for $4 \mathrm{~h}$ at $37^{\circ} \mathrm{C}$ in a $\mathrm{CO}_{2}$ incubator. The MTT containing medium was then discarded and the cells were washed with $200 \mu \mathrm{l}$ of Phosphate Buffer Saline (PBS). The crystals were then dissolved by adding $100 \mu 1$ of Dimethyl Sulfoxide (DMSO) and this was mixed properly. Spectrophotometrical absorbance of the purple blue formazan dye was measured in a microplate reader at $570 \mathrm{~nm}$ using Biorad 680. The data were expressed as the mean percentage of viable cells as compared to the respective control cultures treated with the solvent. The half maximal growth effective concentration $\mathrm{EC}_{50}$ values were calculated against MCF-7 and HeLa cells by checking its corresponding value in the linear equation of the dose dependent curve as referred by Mosmann, 1983.[16]

\section{Results and Discussion}

In the present study, actinobacteria were isolated from the selected soil samples collected from two study sites such as Rameswaram sea and Periyar lake since soil is considered as one of the richest sources for the potential enzyme producing microorganisms especially actinomycetes.

\subsection{Isolation of Actinomycetes}

Among the selected three media used, SCA medium showed the highest colonies (CFU/g) in all the study sites as $16 \times$ $10^{7}, 14 \times 10^{6}$ observed in Rameswaram sea soil and Periyar Lake soil respectively (Table 1 ). Whereas, the ISP-5 medium showed the lowest colonies in both sites as $8 \times 10^{7}$ and $3 \times$ $10^{6}$ in respective Rameswaram sea and Periyar Lake soils. The results indicated that the SCA could serve as a isolation medium compared to other two media tested. Our results were good agreement with the results of Mohan et al., [17] who found that SCA and glycerol asparagine agar medium could be used as selective media for the isolation and enumeration of actinobacteria.

Table 1: Number of Colonies (CFU /g) isolated from soil samples using different medium.

\begin{tabular}{|c|c|c|}
\hline \multirow{2}{*}{ Media } & CFU/g & CFU/g \\
\cline { 2 - 3 } & $\begin{array}{c}\text { Rameswaram } \\
\text { Soil }\end{array}$ & $\begin{array}{c}\text { Periyar Lake } \\
\text { soil }\end{array}$ \\
\hline Starch Casein Agar (SCA) & $16 \times 10^{7}$ & $14 \times 10^{6}$ \\
\hline Actinomycetes Isolation Agar (AIA) & $9 \times 10^{7}$ & $10 \times 10^{6}$ \\
\hline $\begin{array}{c}\text { International Streptomyces Project } \\
\text { (ISP-5) medium }\end{array}$ & $8 \times 10^{7}$ & $3 \times 10^{6}$ \\
\hline
\end{tabular}

\subsection{Screening of L-Asparaginase production}

Isolation of L-asparaginase producing actinomycetes was made and screened for their ability to produce Lasparaginase enzyme. Primarily both M9 and Czapekdox medium used for screening the colonies showed pink colour on plates were considered as positive result for Lasparaginase production. Among the 51 isolates screened, four isolates (three isolates AT-R-S1, AT-R-S2, AT-R-A3 of Rameswaram sea soil and one isolate AT-P-S1 from Periyar lake soil) showed positive results in rapid plate assay

\subsection{Quantitative estimation of L-asparaginase}

Spectrophotometric analysis of the enzyme production was assessed and the results showed that the L-asparaginase production by the isolates were ranged between 0.83 and $3.75 \mathrm{U} / \mathrm{ml}$. The highest production was observed in isolates of Rameswaram sea soil sample (AT-R-S1) and lowest in the isolate of Periyar lake soil sample (AT- P-S1) (Figure 1). The results revealed that the quantity of L-asparaginase production varied with strains. Similarly, Neelima et al., [18] observed the L-asparaginase activity from Streptomyces ginsengisoli at a rate of $3.23 \mathrm{U} / \mathrm{ml}$. Streptomyces nouresi produced $3.310 \mathrm{U} / \mathrm{ml}$ of L-asparaginase as reported by Dharmaraj [20]. Mohana Priya et al., [19] reported that Streptomyces sp TA22 showed that the L-asparaginase activity of $2.46 \mathrm{U} / \mathrm{ml}$.

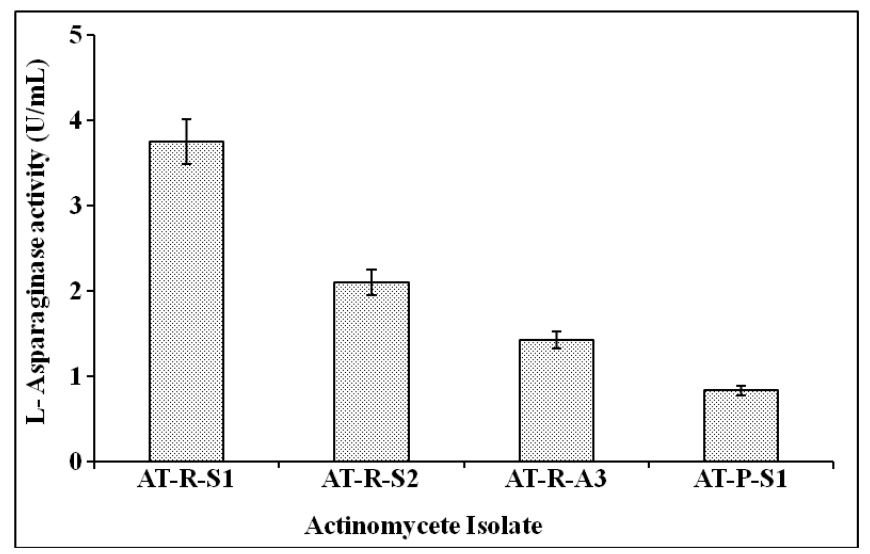

Figure 1: L-asparaginase production by the selected isolates

\subsection{Identification of the isolates}

\subsubsection{Morphological and Biochemical characterization}

For the identification of the strains, morphological, physiological and biochemical characterization were done based on the International Streptomyces Project (ISP). The cultural, morphological and biochemical characteristics of the strains AT-R-S1, AT-R-S2, AT-R-A3 and AT-P-S1 were studied and the results were summarized in Table $2 \& 3$. As summarized in Table 2 all the isolates were found to be gram positive, rod shaped and possessing earthy odour characteristics of actinomycetes. Mycelium was aerial and white in color. Colony elevation was raised with wrinkled and opaque density and tenaciously adhering to the medium. All the isolates were spore forming in nature and spores were non motile, smooth and hairy. The strains exhibited optimum growth under aerobic conditions at temperature $30^{\circ} \mathrm{C} \& \mathrm{pH}$ at 7.0. All the strains were mesophilic and alkaliphilic in nature which showed growth at temperature ranging from 25 to $42^{\circ} \mathrm{C}$ and $\mathrm{pH} 6$ to 10 , but no growth was observed at temperature $4,10,55$ and $65^{\circ} \mathrm{C} \& \mathrm{pH} 5.0$.

\section{Volume 6 Issue 1, January 2017




\section{International Journal of Science and Research (IJSR) \\ ISSN (Online): 2319-7064}

Index Copernicus Value (2015): 78.96 | Impact Factor (2015): 6.391

All the strains of Rameswaram soil showed optimum growth at $2 \%(\mathrm{w} / \mathrm{v})$ sodium chloride $(\mathrm{NaCl})$, but maximum tolerance of $\mathrm{NaCl}$ concentration was $6 \%(\mathrm{w} / \mathrm{v})$, indicating all the isolates were indigenous to marine environment and moderate salt tolerance in nature. The isolate (AT-P-S1) from Periyar Lake survived at $2 \% \mathrm{NaCl}$ and above that concentration no growth was found. All the isolates could utilize arabinose, glucose and mannitol as carbon source. In case of biochemical characterization, all the isolates can have the ability to utilize citrate and the isolates showed negative result to indole test.

Table 2: Morphological and Physiological characterization of the isolated strains - 'No growth; '+'- Normal Growth;

'++'- Moderate Growth; '+++'- Optimum Growth

\begin{tabular}{|c|c|c|c|c|}
\hline TESTS & AT-R-S1 & AT-R-S2 & AT-R-A3 & AT-P-S1 \\
\hline Elevation & Raised & Flat & Flat & Flat \\
\hline Surface & Wrinkled & Wrinkled & Wrinkled & Wrinkled \\
\hline Density & Opaque & Opaque & Opaque & Opaque \\
\hline Pigment & Brown & White & $\begin{array}{c}\text { Yellowish } \\
\text { Brown }\end{array}$ & Black \\
\hline $\begin{array}{c}\text { Grams } \\
\text { Reaction }\end{array}$ & $+\mathrm{ve}$ & $+\mathrm{ve}$ & $+\mathrm{ve}$ & $+\mathrm{ve}$ \\
\hline $\begin{array}{c}\text { Spore } \\
\text { Chains }\end{array}$ & Spiral & Spiral & Spiral & Spiral \\
\hline Mycelium & Aerial & Aerial & Aerial & Aerial \\
\hline $\begin{array}{c}\text { Spore } \\
\text { Motility }\end{array}$ & Non motile & Non motile & Non motile & Non motile \\
\hline $\begin{array}{c}\text { Spore } \\
\text { surface }\end{array}$ & $\begin{array}{c}\text { Smooth \& } \\
\text { hairy }\end{array}$ & $\begin{array}{c}\text { Smooth \& } \\
\text { hairy }\end{array}$ & $\begin{array}{c}\text { Smooth \& } \\
\text { hairy }\end{array}$ & $\begin{array}{c}\text { Smooth \& } \\
\text { hairy }\end{array}$ \\
\hline \multicolumn{5}{|c|}{ Growth at Temperature } \\
\hline 4 & - & - & - & - \\
\hline 10 & - & - & - & - \\
\hline 25 & + & + & + & + \\
\hline 30 & $\begin{array}{c}++ \\
\text { (optimum) } \\
\end{array}$ & $\begin{array}{c}+++ \\
\text { (optimum) }\end{array}$ & $\begin{array}{c}+++ \\
\text { (optimum) }\end{array}$ & $\begin{array}{c}+++ \\
\text { (optimum) }\end{array}$ \\
\hline 37 & ++ & ++ & ++ & ++ \\
\hline 42 & + & ++ & ++ & + \\
\hline 55 & - & \pm & - & - \\
\hline 65 & - & - & - & - \\
\hline \multicolumn{5}{|c|}{ Growth at pH } \\
\hline 5.0 & - & - & - & - \\
\hline 6.0 & + & + & + & + \\
\hline 7.0 & $\begin{array}{c}++ \\
\text { (optimum) }\end{array}$ & $\begin{array}{c}+++ \\
\text { (optimum) }\end{array}$ & $\begin{array}{c}+++ \\
\text { (optimum) }\end{array}$ & $\begin{array}{c}+++ \\
\text { (optimum) }\end{array}$ \\
\hline 8.0 & ++ & ++ & ++ & ++ \\
\hline 9.0 & + & - & + & + \\
\hline 10 & + & - & + & + \\
\hline \multicolumn{5}{|c|}{ Growth on Nacl (\%) } \\
\hline 2.0 & $\begin{array}{c}+++ \\
\text { (optimum) }\end{array}$ & $\begin{array}{c}+++ \\
\text { (optimum) }\end{array}$ & $\begin{array}{c}+++ \\
\text { (optimum) }\end{array}$ & + \\
\hline 4.0 & ++ & ++ & ++ & - \\
\hline 6.0 & + & - & + & - \\
\hline 8.0 & - & - & - & - \\
\hline 10.0 & - & - & - & - \\
\hline
\end{tabular}

Volume 6 Issue 1, January 2017
Table 3: Biochemical test profile of the isolated isolates

\begin{tabular}{|c|c|c|c|c|c|}
\hline Test & $A T-R-S 1$ & \multicolumn{1}{|c|}{$A T-R-S 2$} & $A T-R-A 3$ & $A T-P-S 1$ \\
\hline Biochemical Characteristics \\
\hline Methy Red & - & - & - & - \\
\hline Voges Prousker & + & + & - & - \\
\hline Citrate utilization & + & - & + & + \\
\hline Caesin Hydrolysis & - & - & + & + \\
\hline Starch Hydrolysis & - & + & + & - \\
\hline Urea hydrolysis & + & + & - & + \\
\hline Nitrate reduction & + & + & - & - \\
\hline H2S production & - & + & - & - \\
\hline Catalase test & + & - & - & - \\
\hline Gelatin Hydrolysis & + & + & + & - \\
\hline \multicolumn{2}{|c|}{ Acid Production from Carbohydrates } \\
\hline Arabinose & + & + & + & + \\
\hline Glucose & + & + & + & + \\
\hline Raffinose & + & + & + & - \\
\hline Sucrose & + & + & + & - \\
\hline Xylose & + & + & + & + \\
\hline Fructose & + & + & + & + \\
\hline Mannitol & + & + & + & + \\
\hline Inositol & - & + & + & - \\
\hline Lactose & + & - & + & + \\
\hline
\end{tabular}

\subsubsection{Genotypic characterization of isolates}

For molecular identification of isolates AT-R-S1, AT-R-S2, AT-R-A3 and AT-P-S1, the partial 16S rDNA gene sequence was used. The extracted genomic DNA was amplified using $27 \mathrm{~F}$ and $1492 \mathrm{R}$ primers with suitable cycling condition. The gel image shown in Fig 2 was the amplified products $(\sim 1500 \mathrm{bp})$ electrophoreted in 2 percent agarose gel after PCR amplification. The PCR products were then purified and sequenced followed by homology search analysis. The gene sequences were deposited in the GenBank database and their corresponding accession numbers were given in Table 4

Table 4: List of actinomycetes strains identified using the partial sequences of $16 \mathrm{~S}$ rDNA and their NCBI accession numbers

\begin{tabular}{|c|c|c|c|}
\hline S. No & Name & Host/ Source & Accession No. \\
\hline 1 & $\begin{array}{c}\text { Streptomyces griseoluteus } \\
\text { GDJI }\end{array}$ & Rameswaram soil & KU687334 \\
\hline 2 & $\begin{array}{c}\text { Streptomyces griseoluteus } \\
\text { GDJ2 }\end{array}$ & Rameswaram soil & KU687335 \\
\hline 3 & $\begin{array}{c}\text { Streptomyces griseus } \\
\text { GDJ3 }\end{array}$ & Rameswaram soil & KU687336 \\
\hline 4 & Streptomyces Sp GDJ4 & Periyar lake soil & KU507504 \\
\hline
\end{tabular}

16S rRNA comparisons have been used to investigate the taxonomic status of natural isolates. Among the 4 isolates, 2 isolates (AT-R-S1, AT-R-S2) were identified as Streptomyces griseoluteus, AT-R-A1 and AT-P-S1 were identified as Streptomyces griseus and Streptomyces $\mathrm{Sp}$ respectively (Fig 3).

The isolate Streptomyces griseoluteus GDJ1showed 98\% sequence similarity with the previously published Streptomyces sp INBio_4508H isolated from the gut of the Costa Rican Beetles. Whereas, the isolate Streptomyces griseoluteus GDJ2 showed $99 \%$ sequence similarity with the previously published Streptomyces griseoluteus strain NBRC 13375 collected from NIH, USA. The isolate Streptomyces

\section{www.ijsr.net}

Licensed Under Creative Commons Attribution CC BY 


\section{International Journal of Science and Research (IJSR) \\ ISSN (Online): 2319-7064 \\ Index Copernicus Value (2015): 78.96 | Impact Factor (2015): 6.391}

griseus GDJ3 showed 98\% sequence similarity with the previously published Streptomyces griseoluteus strain NBRC 13375 collected from NIH, USA. The isolate Streptomyces griseus GDJ3 showed 98\% sequence similarity with the previously published Streptomyces griseus strain cfcc3167 collected from Xuzhou, Jiangsu, China. Whereas, the isolate Streptomyces Sp GDJ4 showed 99\% sequence similarity with the previously published Streptomyces sp. ZZY-2013 strain TRM46796-11 collected from Xinjiang, China. From both biochemical and molecular characters of four isolates of present study were belonging to Streptomyces, however they showed dissimilar profiles of biochemical and nutrient utilization.

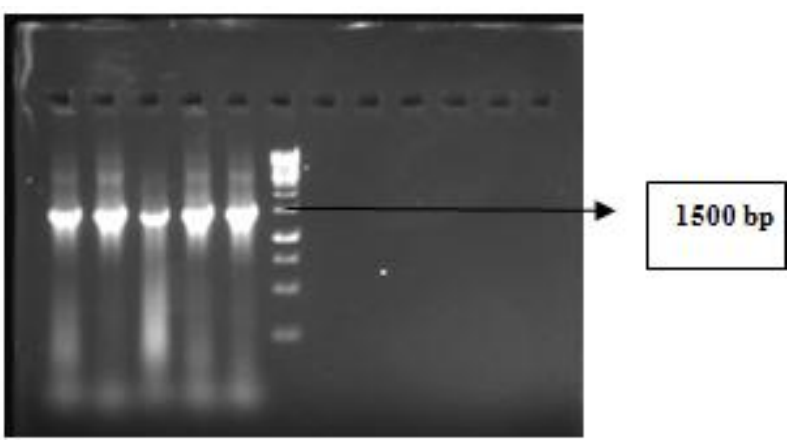

Figure 2: A representative agarose gel showing amplified PCR product of 16S rDNA gene of actinomycetes isolated

from Rameswaram and Periyar lake soil samples. M-

Marker; Lane 1- Positive control; Lane 2 to 5-amplified 16S rDNA PCR product of isolates AT-R-S1, AT-R-S2, ATR-A3 and AT-P-S1

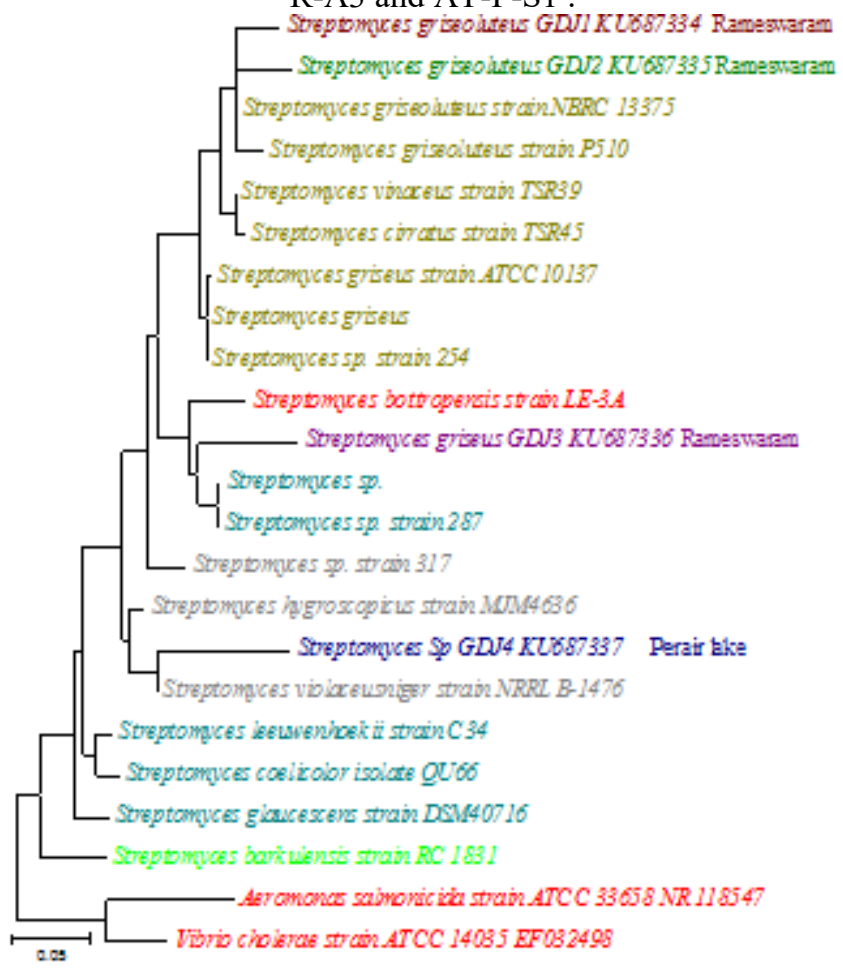

Figure 3: Phylogenetic tree of constructed based on $16 \mathrm{~S}$ rDNA gene sequence of isolates

\subsection{Purification of L-asparaginase}

Based on the enzyme activity, the isolate Streptomyces griseoluteus GDJ1(AT-R-S1) was taken for further study. In the present study, $63.78 \%$ of yield of protein observed after precipitation of crude extract with ammonium sulphate with reduced protein content of $152 \mathrm{mg}$ and increased specific activity of $0.104 \mathrm{U} / \mathrm{mg}$ (Table 5). This shows that the protein get concentrated and purified than the crude extract.[21] Similarly, Dharmaraj [20] reported that the total protein of Streptomyces noursei decreased from 412 to $224 \mathrm{mg}$ and the specific activity increased from 0.803 to $0.933 \mathrm{IU} / \mathrm{mg}$ after ammonium sulphate precipitation step. Whereas, the specific activity of $240,21.21 \mathrm{U} / \mathrm{mg}$ was observed after ammonium sulphate precipitation [22]

The specific activity after Sephadex G-100 filtration was $4.613 \mathrm{U} / \mathrm{mg}$ with the total activity of $5.49 \mathrm{U} / \mathrm{ml}$ (Table 5). The results were comparable with the earlier findings suggested the increasing specific activity and decreased protein content. [20], [23], [24], [25]. After purification with Sephadex G-100 the samples were purified with CM Sephadex C-50 column.

Finally, the specific activity of purified L-asparaginase of Streptomyces griseoluteus GDJ1 (AT-R-S1) in the current study was lower than that of Erwinia chrysanthemi, Elspar ${ }^{\circledR}$ and Oncaspar ${ }^{\circledR}$ and their respective specific activities were 908,270 and $85 \mathrm{u} / \mathrm{mg}$ [26], [27]. The degree of purification of the enzyme affects the enzyme activity and the specific activity. The reason may be that the commercially available enzymes are in highly purified form and the enzyme in the current work is partially purified. Further, additional purification steps have to be carried out to realize its full enzymatic potential. The present study suggests that ammonium sulphate precipitation was found to be highly effective. The Sephadex G-100 and Sephadex C-50 chromatography was found as important for the separation and purification of L-asparaginase. By this purification procedure, the strain Streptomyces griseoluteus GDJ1 (ATR-S1) has produced L-asparaginase with 119 fold purity which is far better than compared to Streptomyces gulbargensis which has shown only 82.12 fold purity [28].

Table 5: Purification profile of L-asparaginase from Streptomyces griseoluteus GDJ1

\begin{tabular}{|c|c|c|c|c|c|}
\hline Purification steps & $\begin{array}{c}\text { Total } \\
\text { activity } \\
\text { (U/ml) }\end{array}$ & $\begin{array}{c}\text { Total } \\
\text { Protein } \\
(\mathrm{mg})\end{array}$ & $\begin{array}{c}\text { Specific } \\
\text { activity } \\
\text { (U/mg) }\end{array}$ & $\begin{array}{c}\text { Purification } \\
\text { fold }\end{array}$ & $\begin{array}{c}\text { Yield } \\
(\%)\end{array}$ \\
\hline $\begin{array}{c}\text { Crude } \\
\text { Extract }\end{array}$ & 24.96 & 212 & 0.117 & - & - \\
\hline $\begin{array}{c}\text { Ammonium sulphate } \\
\text { precipitation }\end{array}$ & 15.92 & 152 & 0.104 & 0.889 & 63.78 \\
\hline $\begin{array}{c}\text { Sephadex G-100 } \\
\text { filtration }\end{array}$ & 5.49 & 1.19 & 4.613 & 39.144 & 21.99 \\
\hline $\begin{array}{c}\text { CM Sephadex C- 50 } \\
\text { Chromatography }\end{array}$ & 1.27 & 0.09 & 14.11 & 119.85 & 5.088 \\
\hline
\end{tabular}

\subsection{Cell line Studies}

\subsubsection{Assessment of cytotoxicity}

To use cancer treatment, L-asparaginase must be devoid of toxicity to normal cells. Hence, the purified L-asparaginase was tested for its toxic potential to VERO cell lines and the results showed that the L-asparaginase did not inhibit the growth (Figure 4). Cytotoxicity of purified L-asparaginase was evaluated on VERO cell line at various concentrations

\section{Volume 6 Issue 1, January 2017




\section{International Journal of Science and Research (IJSR) \\ ISSN (Online): 2319-7064 \\ Index Copernicus Value (2015): 78.96 | Impact Factor (2015): 6.391}

$(5 \mu \mathrm{g}-45 \mu \mathrm{g} / \mathrm{ml})$ for 72 hours and the results were shown in Figure 21. From the results it is evident that the Lasparaginase was not toxic to VERO cell lines even after 72 hours of incubation at the higher concentration. The Lasparaginase doesn't show toxicity to the VERO cell lines up to $45 \mu \mathrm{g}$ which shows $100 \%$ cell viability (Figure 4 ). There were no significant changes observed between the control and treated cells.

The morphology and the cell viability in both control and treated cells showed insignificant change. Hence, it can be concluded that the purified L-asparaginase of Streptomyces griseoluteus GDJ1 (AT-R-S1) was non toxic to normal cell line. Similarly, Husain et al., 2015 showed that Lasparaginase of Enterobacter cloacae was non-toxic to normal CHO cell line. It was shown that nearly $15-20 \%$ of patients treated with L-asparaginase of E. coli develop hypersensitivity and toxicity to the drug. [31], [32], [33], [1].

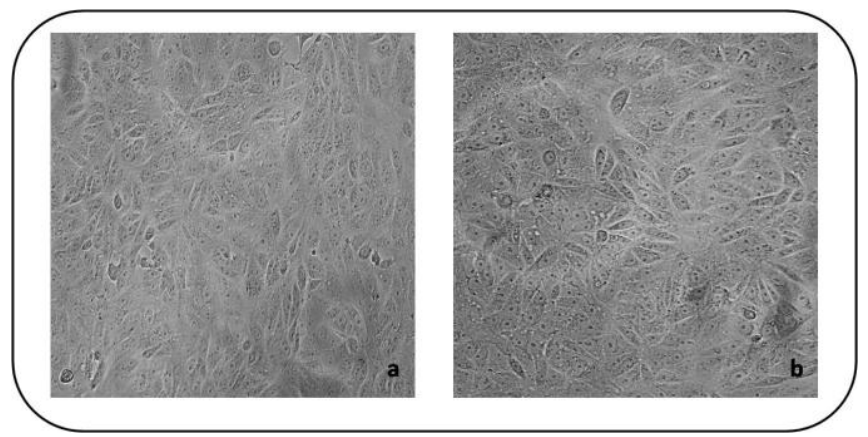

Figure 4: Cytotoxicity of purified L-asparaginase on VERO cell lines, a) Control cell without L-asparaginase and b) cells treated with $45 \mu \mathrm{g} / \mathrm{ml} \mathrm{L-asparaginase} \mathrm{after} 72 \mathrm{~h}$

\subsubsection{Assessment of anti-proliferative activity}

The ultimate aim of the present work is to extract the Lasparaginase with anti proliferative activity. Hence, MCF-7 and HeLa cell line was treated with different concentrations of $(5 \mu \mathrm{g}-45 \mu \mathrm{g} / \mathrm{ml})$ purified L-asparaginase for $72 \mathrm{~h}$ and the percentage of cell death was shown in Table 6 and Figures 5 $\mathrm{a}, \mathrm{b}, \mathrm{c}$. It is clear that the percentage of cell death was gradually increased with increasing concentration of purified enzyme. The reduction in cell viability was linear and highly significant $\left(\mathrm{r}^{2}=0.918\right.$; Figure 5 a). The highest cell death $\%$ $(88.83 \%)$ was observed at the highest concentration $45 \mu \mathrm{g} / \mathrm{ml}$ of L-asparaginase followed by $44.75 \%$ at $25 \mu \mathrm{g} / \mathrm{ml}$ whereas, the lowest cell death was observed at $5 \mu \mathrm{g} / \mathrm{ml}$ of Lasparaginase which was $2.5 \%$. The $\mathrm{EC}_{50}$ value was found to be $31.37 \mu \mathrm{g}$ were $50 \%$ of cell death was occurred (Figure 5 $a, b)$.

Whereas, the L-asparaginase was found to be less toxic to HeLa cell lines compared to MCF-7 (Table 6 and Figures 5 $\mathrm{a}, \mathrm{b}, \mathrm{c})$. The lowest cell death $1.51 \%$ was observed at the lowest concentration of L-asparaginase $(5 \mu \mathrm{g} / \mathrm{ml})$ and the highest $(68.84 \%)$ was at the highest concentration $(45 \mu \mathrm{g} / \mathrm{ml})$ with the $\mathrm{EC}_{50}$ value of $38.99 \mu \mathrm{g}$ (Table 6). The results of the anti-proliferative suggested that the enzyme was highly potent to MCF-7 cells than HeLa cell lines. The higher $\mathrm{EC}_{50}$ is considered to be less active.
The changes in morphology of treated cells were tracked by inverted phase contrast light microscopy. The results revealed that the control of MCF-7 and HeLa cells which were not treated with L-asparaginase showed characteristic spindle shape morphology resembling healthy fibroblasts. MCF-7 and HeLa cells treated with different concentrations of L-asparaginase showed distorted morphology resembling dead fibroblasts which was found to be more at higher concentrations such as 25 and $45 \mu \mathrm{g} / \mathrm{ml}$.

Table 6: Anti proliferative effect of different concentrations of L-asparaginase and its percentage of cell death

\begin{tabular}{|c|c|c|}
\hline $\begin{array}{c}\text { Concentration of } \\
\text { L-asparaginse } \mu \mathrm{g} / \mathrm{ml}\end{array}$ & $\begin{array}{c}\text { Cell death \% of } \\
\text { MCF-7 }\end{array}$ & $\begin{array}{c}\text { Cell death \% of } \\
\text { HeLa }\end{array}$ \\
\hline 5 & 2.512 & 1.51 \\
\hline 10 & 11.95 & 6.45 \\
\hline 15 & 19.38 & 10.39 \\
\hline 25 & 29.72 & 26.72 \\
\hline 35 & 44.72 & 32.72 \\
\hline 45 & 88.84 & 68.84 \\
\hline
\end{tabular}

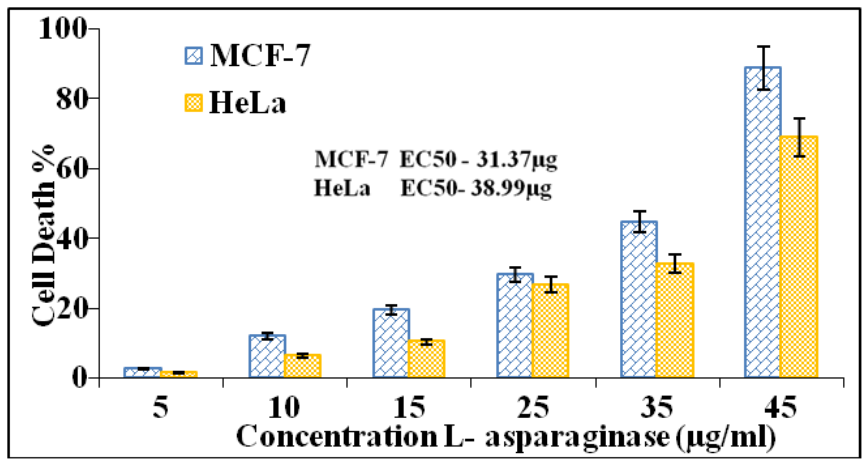

Figure 5: (a) Effect of different concentrations of purified L-asparaginase of Streptomyces griseoluteus GDJ1 (AT-R-

$\mathrm{S} 1)$ on the cell death of MCF-7 and HeLa cell lines.
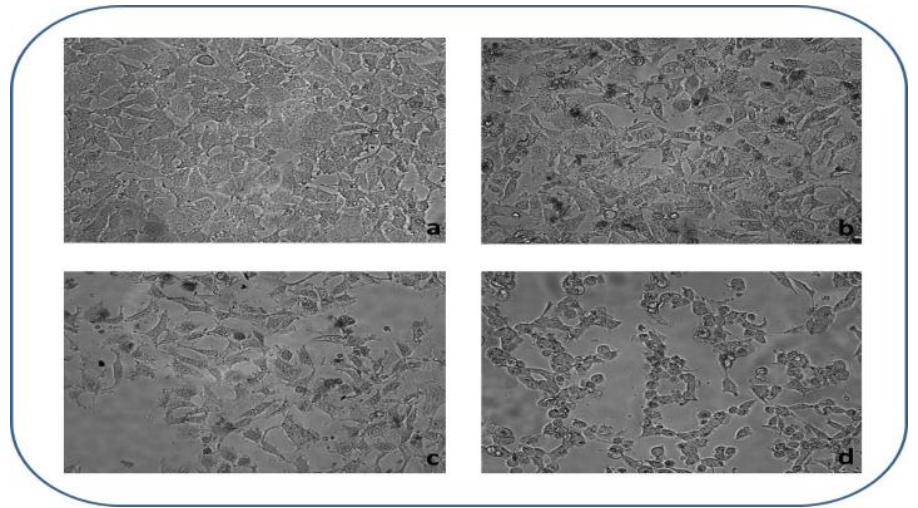

Figure 5: (b). Anti cancer activity of L- asparaginase in MCF-7 cell line. a) Control. b-d) 25,35,45 $\mu \mathrm{g} / \mathrm{ml}$ concentration of L-asparaginase

Both MCF-7 and HeLa cells were treated with different concentrations of $(5 \mu \mathrm{g}-45 \mu \mathrm{g} / \mathrm{ml})$ purified L-asparaginase for $72 \mathrm{~h}$ and the cell death \% was calculated and presented in Table 17 and Figures 5 a, b, c. The cytotoxicity of Lasparaginase was dose dependent and had effect on both cell lines however the MCF-7 was more susceptible than HeLa cells. It has been shown that the cytotoxicity of Lasparaginase differed with sources and cell lines [47] and the $\mathrm{IC}_{50}$ of L-asparaginase of Salinicoccus sp. MKJ997975 against HeLa was $0.171 \mathrm{IU} / \mathrm{ml}$. The study of Oza et al., [34] 


\section{International Journal of Science and Research (IJSR) \\ ISSN (Online): 2319-7064}

Index Copernicus Value (2015): 78.96 Impact Factor (2015): 6.391

showed that L- asparginase of Withania somnifera L. active against acute lymphoblastic leukemia, and Aspergillus flavus (KUFS20) against MCF-7 cell line [35]. L-asparaginase interferes with DNA, RNA and protein synthesis, slowdown the growth and thus impedes cancer cells [36], [37] most specifically to the $G_{1}$ phase of cell division resulted in cell death. However, it is not necessary that all Asparaginases must possess cytotoxicity [29], [38], [40]. According to Song et al., [39] L-asparaginase induce apoptosis during chronic treatment of K562 and KU812 cells.

Lymphoid origin and solid tumors were prone to Lasparginase activity and showed resistant to the drugs among them soft tissue sarcoma [41], ovarian cancer [45], $\beta$-catenin mutated hepatocellular carcinoma [42], hepatocellular carcinoma with low expression of asparagine synthetase [43], and gastric adenocarcinoma [44] were studied. From the literature surveyed and reviewed L-asparaginase exhibited potent anti neoplastic and anti lymphomatic activity against tumors [1], [46], [29], [32], [40] This enzyme causes selective death of asparagines dependent tumor cells and also induces apoptosis in tumor cells [26]. It has been shown that the glutaminase activity affected the normal cell growth [40], [1].. However, several studies depicted that the L-asparaginase activity was depend on the L-glutaminase activity. The effect of these enzymes on the cell lines showed that the L-asparaginase with glutaminase activity has affected the tumor cells than the glutaminase free enzyme [30]. Their data demonstrated that asparaginase activity alone may not be sufficient for asparaginase cytotoxicity, and that glutaminase activity may be required for full anti-leukemic efficacy. The morphological changes during apoptosis include membrane blebbing, cell shrinkage was also observed with dose depended manner which was similar to the observations of Husain et al., [29]. As a whole, the purified L-asparaginase of Streptomyces griseoluteus GDJ1 (AT-R-S1) did not inhibit the growth of VERO cells upto $45 \mu \mathrm{g} / \mathrm{ml}$ whereas at $45 \mu \mathrm{g} / \mathrm{ml}$ concentration nearly $88 \%$ of cell death of MCF-7 cells was observed. This observation led us to suggest that the purified enzyme has specific antitumor activity to cancer cells and could be safe for normal cells.
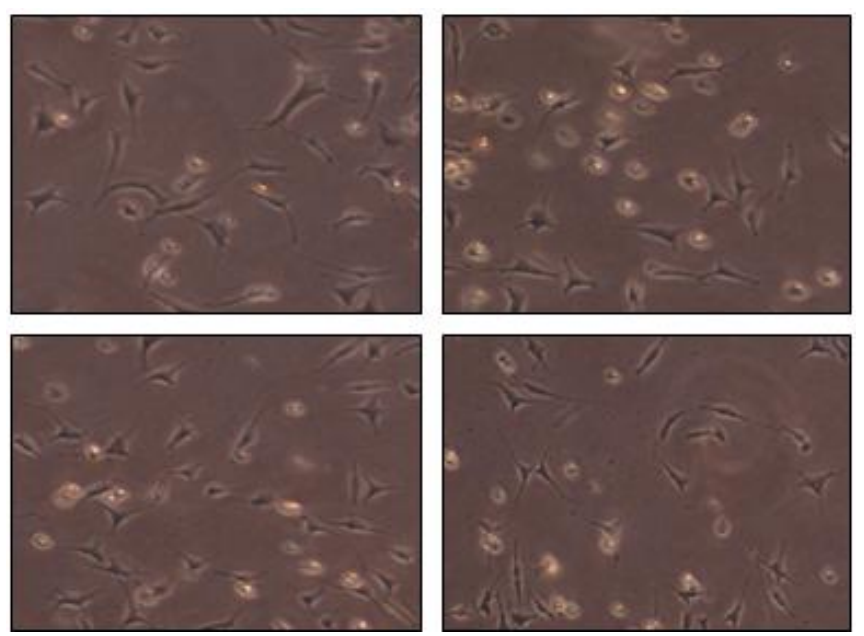

Figure 5: (c). Anti cancer activity of L- asparaginase in HeLa cell line. a) Control. b-d) 25,35,45 $\mu \mathrm{g} / \mathrm{ml}$ concentration of L-asparaginase.

\section{Conclusion}

The ultimate aim of the present work is to extract the Lasparaginase with anti proliferative activity. For this, actinomycetes were isolated and screened for L-asparaginase activity from the soil samples of Rameswaram and Periyar lake. Based on the quantification studies, AT-R-S1 was selected for further studies and the strain was identified as Streptomyces griseoluteus GDJ1 based on molecular identification. Purification of the enzyme from the strain S.griseoluteus GDJ1 (AT-R-S1) was carried out. Cytotoxicity of different concentration of purified Lasparaginase was determined on VERO cells. The Lasparaginase doesn't show toxicity to the VERO cell lines up to $45 \mu \mathrm{g}$ which showed $100 \%$ cell viability. The anti proliferative activity of L-asparaginase in MCF-7 and HeLa cells was determined and the $\mathrm{EC}_{50}$ value was found to be 31.37 and $38.99 \mu \mathrm{g}$ respectively. The results of the antiproliferative suggested that the enzyme was highly potent to MCF-7 cells than HeLa cell lines.

The above results were encouraging and worth pursuing for further development of Streptomyces griseoluteus GDJ1 (AT-R-S1) as an alternative resource for therapeutic Lasparaginase. Protein sequencing, gene identification and other bioinformatics parameters help further in establishing the value of the Streptomyces griseoluteus GDJ1 (AT-R-S1). Finally to conclude, L-asparaginase from Streptomyces griseoluteus GDJ1 (AT-R-S1) is the potential enzyme which has therapeutic and industrial applications.

\section{References}

[1] T. Batool, E. A. Makky, M. Jalal, M.M. Yusoff, "A comprehensive review on $\mathrm{L}$ asparaginase and its applications," Applied Biochemistry and Biotechnology, 178 (5), pp. 900-923. 2016.

[2] A. Sabu, "Sources, properties and applications of microbial therapeutic enzymes," Indian Journal of Biotechnology, 2 (3). pp. 334-341, 2003.

[3] L.A. Torre, F. Bray, R.L. Siegel, J. Ferlay, J. Lortet-Tieulent, A. Jemal, "Global cancer statistics 2012," CA: a cancer journal for clinicians, 65(2). pp. $87-108,2015$.

[4] M. Jain, R. Nilsson, S. Sharma, N. Madhusudhan, T. Kitami, A.L. Souza, R. Kafri, M.W. Kirschner, C.B. Clish, V.K. Mootha, "Metabolite profiling identifies a key role for glycine in rapid cancer cell proliferation," Science, 336 (6084), pp. 1040-1044, 2012.

[5] N.M. Kumar, C.A. Shimray, D. Indrani, H.K. Manonmani, "Reduction of acrylamide formation in sweet bread with 1-asparaginase treatment," Food and bioprocess technology, 7(3), pp. 741-748, 2014.

[6] I.L. Andrulis, R. Argonza, A.E.L. Cairney, "Molecular and genetic characterization of human cell lines resistant tol-asparaginase and albizziin," Somatic cell and molecular genetics, 16(1), pp. 59-65, 1990.

[7] M.J. Keating, R. Holmes, S. Lerner, D.H. Ho, "Lasparaginase and PEG asparaginase past, present, and future," Leukemia \& lymphoma, 10(1), pp.153-157, 1993. 


\section{International Journal of Science and Research (IJSR) \\ ISSN (Online): 2319-7064}

Index Copernicus Value (2015): 78.96 | Impact Factor (2015): 6.391

[8] O.V. Kravchenko, T.A. Kislitsin, A.N. Popov, S.V. Nikonov, I.P. Kuranova, I. P, "Three-dimensional structures of 1-asparaginase from Erwinia carotovora complexed with aspartate and glutamate," Acta Crystallographica Section D: Biological Crystallography, 64(3), pp.248-256, 2008.

[9] A. Shrivastava, A.A. Khan, M. Khurshid, M.A. Kalam, S.K. Jain, P.K. Singhal, "Recent developments in 1asparaginase discovery and its potential as anticancer agent," Critical reviews in oncology/hematology, 100, pp 1-10, 2016.

[10] R. Gulati, R.K. Saxena, R.K. R. Gupta, "A Rapid plate assay for screening L-asparaginase producing microorganisms," Letters in Applied Microbiology 24, pp.23-26, 1997.

[11]A. Imada, S. Igarasi, K. Nakahama, M. Isono, "Asparaginase and glutaminase activities of microorganisms,” Microbiology, 76(1), pp.85-99, 1973.

[12] C.R. Kokare, K.R. Mahadik, S.S Kadam, B.A. Chopade, B.A, "Isolation, characterization and antimicrobial activity of marine halophilic Actinopolyspora species AH1 from the west coast of India," Curr. Sci. 86, pp. 593-597, 2004.

[13]E.B. Shirling, D. Gottlieb, "Methods for characterization of Streptomyces species, ” Int., J., Syst., Bacteriol. 16, pp.312- 340, 1966.

[14] J.A. Distasio, R.A. Niederman, D. Kafkewitz, D. Goodman, "Purification and characterization of Lasparaginase with anti-lymphoma activity from Vibrio succinogenes," Journal of Biological Chemistry, 251(22), pp. 6929-6933, 1976.

[15] S.L. Dellaporta, J. Wood, J.B. Hicks, J.B, "Isolation of DNA from higher plants. Plant," Mol Biol Rep. 4, pp.19-21, 1983.

[16] T. Mosmann, "Rapid colorimetric assay for cellular growth and survival: application to proliferation and cytotoxicity assays," J. Immunol. Methods, 65, pp.5563, 1983.

[17] Y.J. Mohan, B. Sirisha, K. Prathyusha, P. Rao, "Isolation, Screening and Characterization of Actinomycetes from Marine Sediments for their Potential to Produce Antifungal Agents," Journal of Advanced Biotech, 4(3), pp.456-459, 2014.

[18] Neelima Deshpande, Prachi Choubey, Manasi Agashe, "Studies on optimization of growth parameters for Lasparaginase production by Streptomyces ginsengisoli," The Scientific World Journal, 895167, pp.01-06, 2014.

[19] P.Mohana Priya, M. Radhakrishnan, R. Balagurunathan, "Production and optimization of L-asparaginase from Streptomyces sp (TA22) isolated from Western Ghats," India. J Chem Pharm Res, 3, pp. 618-662, 2011.

[20] S. Dharmaraj, "Study of L-asparaginase production by Streptomyces noursei MTCC 10469, isolated from marine sponge Callyspongia diffusa," Iran J Biotechnol, 9(2), pp. 102-108, 2011.

[21]P. Dhevagi, E. Poorani, E, "Isolation and characterization of L-asparaginase from marine actinomycetes," Indian Journal of Biotechnology, 5, pp. $514-520,2006$.

[22] A.P. Chandrasekhar, "Isolation, purification and characterization of asparaginase from aspergillus species," International Journal of Research in Chemistry and Environment, 2, pp. 38-43, 2012.

[23] Palaniappan Sivasankar, Shanmugam Sugesh, Packiyaraj Vijayanand, Kannan Sivakumar, Shanmugam Vijayalakshmi, Thangavel Balasubramanian., Packium Mayavu, "Efficient production of 1-asparaginase by marine Streptomyces sp. isolated from Bay of Bengal, India," African Journal of Microbiology Research, 7(31), pp. 4015-4021, 2013.

[24] Sabha Mahmoud El-Sabbagh, Nadia Hamed ElBatanony, Tarek A. Salem, "L-asparaginase produced by Streptomyces strain isolated from Egyptian soil. Purification, characterization and evaluation of its antitumor," African Journal of Microbiology Research. 7(50), pp. 5677-5686, 2013.

[25] M.S. Shafei, Heba A El Refai, H. Mostafa, S. Gomaa, S, "Purification, characterization and kinetic properties of penicillium cyclopium L-asparaginase. Impact of lasparaginase on acrylamide content in potato products and its cytotoxic activity," Current Trends in Biotechnology and Pharmacy. 9(2), pp. 132-140, 2015.

[26] Kelo Eira, Tiina Noronkoski, Ivanka B Stoincva, Dimiter D Petkov., Ilkka Mononen, "Beta aspartidyl peptides as substrates of L-asparaginase from E.coli and E.chrysanthemi," Letters. 528, pp. 130-2, 2002.

[27]D. Gervais, N. Foote, "Recombinant deamidated mutants of Erwinia chrysanthemi L-asparaginase have similar or increased activity compared to wild-type enzyme," Molecular biotechnology, 56(10), pp. 865 877,2014

[28] S. Amena, N. Vishalakshi, M. Prabhakar, A. Dayanand, K. Lingappa, "Production, purification and characterization of L-asparaginase from Streptomyces gulbargensis," Brazilian journal of Microbiology, 41(1), pp. 173-178, 2010.

[29] I. Husain, A. Sharma, S. Kumar, F. Malik, "Purification and characterization of glutaminase free asparaginase from Pseudomonas otitidis: Induce apoptosis in human leukemia MOLT-4 cells," Biochimie, 121, pp. 38-51, 2015.

[30] J.H. Parmentier, M. Maggi, E. Tarasco, C. Scotti, V.I. Avramis, S.D. Mittelman, "Glutaminase activity determines cytotoxicity of L-asparaginases on most leukemia cell lines," Leuk. Res. 39, pp. 757-762, 2015.

[31] Ivana Hermanova, Marketa Zaliova, Jan Trka, Julia Starkova, "Low expression of asparagine synthetase in lymphoid blasts precludes its role in sensitivity to Lasparaginase," Experimental Hematology. 40, pp. $657-$ $665,2012$.

[32] Emadi Ashkan, Hania Zokaee, Edward A. Sausville, "Asparaginase in the treatment of non- ALL hematologic malignancies," Cancer Chemother Pharmacol. 73, pp. 875-883, 2014.

[33] Krishnapura Prajana Rao, Prassana D. Belur, Sandeep Subramanya, "A critical review on properties and applications of microbial L-asparaginases," Critical reviews in Microbiology. pp. 01-18, 2015.

[34] V.P. Oza, S.D. Trivedi, P.P Parmar, R.B. Subramanian, "Withania somnifera (Ashwagandha): a Novel Source of L-asparaginase," Journal of integrative plant biology, 51(2), pp.201-206, 2009. 


\section{International Journal of Science and Research (IJSR) \\ ISSN (Online): 2319-7064}

Index Copernicus Value (2015): 78.96 Impact Factor (2015): 6.391

[35] V.P. Oza, S. Kumar, P.P. Parmar, R.B. Subramanian, "Anti-cancer properties of highly purified l-asparaginase fromWithania somnifera L. against acute lymphoblastic leukemia," Appl Biochem Biotechnol. 160, pp. 18331840, 2010.

[36] Stams Wendey, Monique L. den Boer, Amy Holleman, Inge M. Appel, Berna Beverloo, Elisabeth R.van Wering, Gritta E. Janka-Schaub, William E.Evan, Rob Pieters., "Asparagine synthetase expression is linked with L-asparaginase resistance in TEL-AML1-negative but not TEL-AML1-positive pediatric acute lymphoblastic leukemia," Blood. 105, pp. 4223-4225, 2005.

[37] S. Ghosh, S.R. Chaganti, R.S. Prakasham, R. S, "Polyaniline nanofibers as a novel immobilization matrix for the anti-leukemia enzyme L- asparaginase," Journal of Molecular Catalysis B : Enzymatic. 74(1-2), pp.132-137, 2011.

[38] M.E. Rytting, "Role of L-asparaginase in acute lymphoblastic leukemia: focus on adult patients," Blood and Lymphatic Cancer: Targets and Therapy, 2, pp.117124, 2011.

[39] P. Song, L. Ye, J. Fan, Y. Li, X. Zeng, Z. Wang, S. Wang, G. Zhang, P.Yang, Z. Cao, D. Ju, “Asparaginase induces apoptosis and cytoprotective autophagy in chronic myeloid leukemia cells," Oncotarget, 6(6), pp.3861-3873, 2015.

[40] Ali., Muhammad Naveed, Abid Ullah, Khadija Ali, Sayed Afzal Shah, Shah Fahad, Abdul Samad Mumtaz, "L-asparaginase as a critical component to combat Acute Lymphoblastic Leukaemia (ALL): A novel approach to target ALL," European Journal of Pharmacology. 771, pp. 199-210, 2016.

[41]B. Clarkson, I. Krakoff, J. Burchenal, "Clinical results of treatment with $E$. coli L-asparaginase in adults with leukemia, lymphoma, and solid tumors," Cancer 25(2), pp. 279-305, 1970

[42] Lorenzi Philip, Jenny Llamas, Michalae Gunsior, John Weinstien, "Asparagine synthetase is a predictive biomarker of L-asparaginase activity in ovarian cancer cell lines," Molecular Cancer Therapeutics. 7(10), pp. 3123-8, 2008.

[43] P.L. Lorenzi, W.C. Reinhold, M. Rudelius, “Asparagine synthetase as a causal, predictive biomarker for Lasparaginase activity in ovarian cancer cells," Mol Cancer Ther. 5(11), pp. 2613-2623, 2006.

[44] S. Tardito, M. Chiu, J.Uggeri, A. Zerbini, F. Da Ros, V. Dall'Asta, G. Missale, O. Bussolati, "L-Asparaginase and inhibitors of glutamine synthetase disclose glutamine addiction of $\beta$-catenin-mutated human hepatocellular carcinoma cells," Curr Cancer Drug Targets. 11(8), pp. 929-43, 2011.

[45] S. Tardito, J. Uggeri, C. Bozzetti, M.G. Bianchi, B.M. Rotoli, R. Franchi, G. Gazzola, C. Gazzola, C. Gatti, O. Bussolati, "The inhibition of glutamine synthetase sensitizes human sarcoma cells to Lasparaginase," Cancer Chemother Pharmacol. 60, pp. 751-758, 2007.

[46] M.K. Sahu, E. Poorani, K. Sivakumar, T. Thangaradjou, L. Kannan, "Partial purification and anti-leukemic activity of L-asparaginase enzyme of the actinomycete strain LA-29 isolated from the estuarine fish, Mugil cephalus (Linn.)," Journal of Environmental Biology, 28(3), pp. 645, 2007.

[47] Shakambari Ganeshan, Anand Kumar Birendranarayan, Maria Joseph Angelaa, Lincy, Sameer Kumar, Rai Quazi Taushif Ahmad, Balasubramanian Ashokkumar, Matheshwaran Saravanan, Ayyavu Mahesh, Perumal Varalakshmi., "Correction: Hemocompatible glutaminase free L-asparaginase from marine Bacillus tequilensis PV9W with anticancer potential modulating p53 expression," RSC Adv, 6, 32089, 2016. 